Vol. 17, n² | 2013

Varia

\title{
A State within 'The States' : Private Policing and Delegation of Power in America
}

Wilbur R. Miller

\section{OpenEdition}

\section{Journals}

\section{Electronic version}

URL: http://journals.openedition.org/chs/1434

DOI: $10.4000 /$ chs. 1434

ISSN: 1663-4837

\section{Publisher}

Librairie Droz

\section{Printed version}

Date of publication: 1 December 2013

Number of pages: 125-135

ISBN: 978-2-600-01776-3

ISSN: $1422-0857$

\section{Electronic reference}

Wilbur R. Miller, «A State within 'The States' : Private Policing and Delegation of Power in America », Crime, Histoire \& Sociétés / Crime, History \& Societies [Online], Vol. 17, n² | 2013, Online since 01

December 2016, connection on 20 April 2019. URL : http://journals.openedition.org/chs/1434; DOI : $10.4000 /$ chs. 1434 


\title{
A State within 'The States': Private Policing and Delegation of Power in America
}

\author{
Wilbur R. Miller
}

$\mathrm{W}$ here there is a state, there is policing. Law enforcement and order maintenance, though, vary according to the nature of the state itself. In addition to patterns of local control, systemic corruption and violent 'street corner justice', American policing includes a long tradition of the coexistence of private policing with the forces of the state. Private policing, broadly defined as control of crime and disorder by individuals, organized groups, or profit-making companies, is usually taken to suggest the inability or unwillingness of the state to uphold law and order. ${ }^{1}$ The overview that follows proposes to modify this viewpoint by showing how the state has often directly or tacitly supported various forms of private policing since the beginnings of public police forces in the mid-nineteenth century. This is not to say that a weak state was not a factor, but that private policing persisted even as the state grew stronger with a longer reach. The state on the national and local level was willing to delegate some of its power. Additionally, the persistence of private policing shows a more complex pattern than Lawrence Friedman's argument that a "master truth" of the history of policing in the United States has been evolution from amateur to professional, private to public. ${ }^{2}$ Indeed in the United States since the nineteenth century, private police became a state within the state, not as a rival to the state but often cooperating with its forces.

The State, both the Federal government and individual states ${ }^{3}$ has supported private policing from the individual to the organizational level. ${ }^{4}$ First, several individual states have expanded personal self-defense to include carrying of firearms and immediate response to perceived threats. Second, states have tacitly or explicitly sanctioned vigilante groups such as rural and urban crusaders against gambling, prostitution, obscenity or general disorder. The federal government has endorsed some private policing operations by sharing information, relying on their investigations, and in some cases granting official approval and powers, as in the case of various anti-radical groups during World War I and the Cold War. Third, states have sanctioned law enforcement institutions, often private profit-making businesses

\footnotetext{
1 Spierenburg, (2006). See also Mennell (2007, p.147). Both authors base their argument on Norbert Elias' 'Civilizing Process' theory, which includes development of state control of internal violence. Friedman (1993, p. 174).

To avoid the inevitable confusion among European readers, I will indicate which level of 'the state' by phrases such as the above, or use of the plural. Other times the context should make it clear.

$4 \quad$ Private prisons and the unique American industry of bail bondsmen are private institutions that play a major role in the U.S. criminal justice system, though neither are strictly private policing.
} 
acting independently, such as private detective agencies and company police, or contracting to perform government functions including national security. Private police are both less restrained and more limited than public police forces. They are less restrained because they are usually not subject to the legal limits imposed on state police; more limited because they patrol and enforce laws in limited spaces for specific employers to whom they are loyal.

\section{ARMED CITIZENS AND SELF-DEFENSE}

If self-defense comes within the broad definition of private policing given earlier, it is the oldest in the world and hardly limited to the United States. Its roots lie in the absence of any public policing, but in the later twentieth century several states sanctioned it as a supplement to public police, a political assertion of the individual's freedom to respond to crime outside of the state apparatus.

Southern and Western states, with their culture of personal honor and tradition for carrying firearms, strengthened self-defense by authorizing concealed or open weapons with few limitations of where or when. These laws are part of a broader campaign to expand the Constitutional right to "keep and bear arms" as much as possible. More practically, supporters argue that the armed citizen is a powerful deterrent to crime. Gun-toting citizens do not see themselves as defying the state: they have state sanction through licensing and weapons training requirements. Even in Arizona, which first allowed concealed and most recently open weapons without a license, it is the state which specifically legitimates the practice. ${ }^{5}$ Southern and Western state legislatures do not consider policing solely a public or official responsibility but a role for ordinary citizens as well. This attitude recalls Alexis de Tocqueville's view that, unlike Europe where crime is the exclusive concern of the state, American citizens took and active role in suppressing it. ${ }^{6}$

Not only do these states authorize weapons for self-protection, some have rejected the common law 'duty to retreat' as necessary for a plea of self-defense, whereby the person who is threatened has to show that he tried to escape and killed the assailant only as a last resort. New York law, for example, currently mandates a duty to retreat even from intruders into one's own home, but only if one knows that he or she can safely retreat without harm to oneself of others. Deadly force, without qualification is justified when in his or her home, a person intrudes and is about to commit kidnapping, rape, arson, or even burglary. ${ }^{7}$ Some states, Florida being the first in 2002, have gone further, justifying deadly force against muggers or other criminals in any public place. ${ }^{8}$ Such weakening of the 'duty to retreat' are often called 'stand your ground laws', and the Supreme Court upheld the principle in

5 Gun Owners All across the U.S. Applauded Arizona's Enlightened Stance toward Guns for Self Defense [http://www. armed citizens network.org/images/stories.Hayes-SDLaw.PDF] p.15, retrieved 1 Aug. 2010, and New York Times, 5 Dec. 2010, p. A1, retrieved 16 Nov. 2012.

6 de Tocqueville (1862 I, p. 120).

$7 \quad$ [http ://www.selfdefenses.com/forcespray/SD-law.html], retrieved 5 Aug. 2010.

8 [htttp://www.us-today.com/news/nation/2006-03-20-states-self-defense_x.htm], retrieved 5 Aug. 2010. 
1895 and 1921 (Beard vs. U.S., 1895 ; Brown vs. U.S., 1921). ${ }^{9}$ Justice Holmes wrote in 1921 that the principle that a "reasonable man" was bound to retreat was too rigid to apply when an ordinary man under stress was directly threatened with a knife. ${ }^{10}$ The recent state laws made explicit what often had been assumed or developed in case law. 'Stand your own ground' is not a blanket justification for self-defense: it does not permit resistance to the police or protection of a fugitive from justice in one's home. These laws seem to be symbolic statements, an assertion that citizens may protect themselves when threatened instead of having to depend on public officials. ${ }^{11}$ In the United States, self-defense carries considerable emotional weight: many Americans identify democracy itself with self-defense. ${ }^{12}$

\section{BOUNTY HUNTERS}

A short step above armed citizens are bounty hunters, a little-known but pervasive form of private policing. Rewards for capture of criminals, 'dead or alive' were issued by both states and private institutions such as railroad companies in the nineteenth century. Ordinary citizens could claim the rewards for capture or information, but bounty hunters also developed as a profession. In 1872 Supreme Court Justice Swayne declared that sureties (holders of bail) "may exercise their rights in person or by agent. They may pursue him (the bail-jumper) into another state; may arrest him on the Sabbath, and, if necessary, may break and enter his house for that purpose" ${ }^{13}$ This has been interpreted to allow bounty hunters as agents to ignore the usual legal limits of police powers. Bounty hunters are active today as enforcers for the bail-bond industry ${ }^{14}$ seeking and capturing people who have jumped bail. They actually capture more 'skips' than the police. A quick search of the internet reveals ads for training programs and job opportunities. Several websites offer on-line criminal justice degrees for potential bounty hunters. Texas grants a private investigators' license to qualified individuals. New Jersey recently enacted a law requiring a license but with a very short training period. ${ }^{15}$ It is not surprising that there have been major problems with bounty hunting in recent years: criminals pretending to be pursuing fugitives, bounty hunters harassing the wrong people, and violence connected with their activities. ${ }^{16}$

$9 \quad$ See Brown (1991) [http://supreme.justia.com/cases/federal/us/158/550/case.html]; [http ://supreme. justia.com/cases/federal/us/256/335/case.html], both retrieved 23 Nov. 2012.

10 [http ://supreme.justia.com/cases/federal/us/256/335/case.html].

11 The 2011 killing in Florida of Travon Martin by a neighborhood watch member, not authorized by the police to carry a weapon, indicates more than symbolic significance and has raised serious questions about these laws. A trial is pending, after a period of state reluctance to prosecute.

12 Spierenburg (2006, pp. 107-108 \& 110).

13 Taylor vs. Taintor, 1872 [http://supreme.justia.com/cases/federal/us/83/366/case.html\#F15], retrieved 23 Nov. 2012.

14 Bail bonds as a business, charging a fee to post bail for defendants, is uniquely American. The first company was founded by Peter McDonough of San Francisco in 1898. See obituary of McDonough in San Francisco Chronicle, 10 July 1947.

15 Newark Star Ledger, 8 Aug. 2010, p. 24.

16 [http://www.slate.com/articles/news_and_politics/the_gist/1997/09/bounty_hunters.html] retrieved 18 Nov. 2012. 


\section{VIGILANTES}

Private policing by citizens' groups, vigilantism, is essentially organized selfdefense for a limited period of time. Many vigilantes used violence to maintain order in the face of unwilling or ineffective public officials, but also with official tacit or overt support. Richard M. Brown classified vigilante movements as either 'socially constructive' or 'socially destructive.' The socially constructive type enforced majority values against outlaws or other people considered immoral or undesirable. Once they achieved their aim they usually disbanded. Destructive movements simply led to counter movements and prolonged local warfare. ${ }^{17}$ The 'constructive' type often operated parallel to functioning law enforcement institutions, and in many cases received official sanction.

The Ku-Klux Klan and other white supremacist vigilantes evolved from fighting individual state governments into a violent auxiliary of several Southern States. During Reconstruction (1868-1877) white supremacists used violence and intimidation to overthrow Republican state governments based on African-American voting. After the collapse of Reconstruction, political disfranchisement of blacks and full social segregation gradually emerged, fully in place by the early 1900s. Now white supremacist groups operated with the tacit acceptance of state officials. Although a few local Sheriffs resisted lynch mobs in the name of due process of law, most were absent or stood aside when crowds broke into jails to seize black prisoners. Lynch mobs and vigilante groups were essentially upholding segregation alongside the states. Following the Brown v. Board of Education Supreme Court decision and later civil rights laws of the 1960s, individual states waged a campaign of resistance to the national state. Resistance to the 'Second Reconstruction' was on the level of official state efforts to 'nullify' or 'interdict' federal laws, and on the private level of open citizens' groups and secret white-supremacy vigilantes, sometimes murderers of civil-rights activists. Groups of businessmen founded 'White Citizens' Councils' during the Civil-Rights era, beginning in Mississippi in 1954. They enforced economic sanctions against people challenging segregation laws. ${ }^{18}$ They had the full co-operation, indeed endorsement, of the state officials. Violent groups like the Klan had many police officers as members, who were essentially upholding the system of segregation by both official and private means.

American vigilantism is usually associated with the western and southern states, but northeastern cities had their own vigilantes, crusaders against prostitution, gambling, obscenity and corruption. State governments, often in political conflict with city governments, endorsed these anti-vice reformers, like Anthony Comstock and Rev. William Parkhurst in New York City, by giving their anti-obscenity and anti-corruption investigators arrest powers. These and later reformers hired amateur undercover agents and professional private detectives to gather evidence against the underworld of vice. In these cases city police were unwilling to act because illegal vice was a lucrative source of payoffs. ${ }^{19}$ Federal agencies like 'Immigration and Naturalization' and the Bureau of Investigation (renamed FBI in 1924) supported

\footnotetext{
17 Brown (1969, pp. 171-177).

18 McMillen (1971).

19 Fronc (2009).
} 
reformers' efforts by enforcing such measures as the Mann Act of 1911 which outlawed interstate traffic in prostitutes.

World War I marked the beginning of the Federal government's policing of radical left-wing groups thought to threaten national security. ${ }^{20}$ It carried on its political policing with the support of state-approved vigilante groups. The largest was the American Protective League, which claimed 2500 members in 600 cities when it began in 1917. Its official mission was to help the federal government combat not only German spies, but organizations considered a threat to the war effort: pacifists, left-wing groups, and militant labor unions. Attorney General Gregory endorsed these activities and considered the APL a valuable aid to the undermanned and limited Bureau of Investigation. It also provided volunteer spies for the Military Intelligence Division, with similar targets. The largest single activity of the APL was attacks on the I.W.W. (Industrial Workers of the World), a militant anti-war labor organization. In this case they acted as police on behalf of employers, especially in the West, where the I.W.W. was strong. Local APL groups also conducted 'slacker raids', rounding up young men they accused of evading the military draft. The APL thereby functioned as a government auxiliary.

Despite many people's desire for the APL to carry on after the war, its founders disbanded the group in 1919. Members, though, continued to provide private police and spy services, supplying information about radicals to J. Edgar Hoover of the Attorney General's Office, who organized mass arrests and deportations of Communists and other leftists during the red scare of 1919-1920. The American Legion, organized after the war, provided vigilantes to harass radical union organizers. In Centralia, Washington, a Legionnaire raid on an I.W.W. meeting led to a fight in which five of the vigilantes were killed and a union organizer was lynched. In 1919 the American Civil Liberties Union reported fifty episodes of Legionnaire violence. ${ }^{21}$ Under Hoover's FBI predecessor, William Burns, the bureau cooperated with private anti-communist groups to identify radicals. During the twenties the National Civic Association, strongly anti-union after the death of its conservative unionist member Samuel Gompers, worked with Burns. Its leader, Ralph Easley wrote several frantic pamphlets about the red menace. In New York, the state senate Lusk investigation used information from private groups, who in turn cited its very dubious findings in their attacks on individuals they considered subversive. ${ }^{22}$ In the 1930s, when intensive union organizing met equally intensive efforts to thwart it, many local posts of the American Legion continued their role as hit men for employers. In California, the Legion, local police and employer's associations defeated Communist-led efforts to organize migrant agricultural workers. Similarly in the 1934 San Francisco dockworker's strike, Legionnaires joined local police and employers in a fierce, often physical fight to break the union.

The Wagner act of 1935 is usually seen as ending the government's anti-union position. That was true of the Federal Government, but state and local officials continued to accept private organizations to combat organizing by the Congress of Industrial Workers (CIO) which had launched a drive to unionize steel and

\footnotetext{
$20 \quad$ Ibid., Ch. 6.

21 Shrecker (1998, pp. 61-63).

22 Hapgood (1927, pp. 44-48;107-112 \& 157-159).
} 
automobile workers. The American Legion joined local police who were beating up strikers and the union effort was blocked for several years. ${ }^{23}$

The FBI and private anti-communist groups continued to co-operate in the second red scare after World War II. During the war and Cold War the FBI operated an 'American Legion Contact Program.' Although its primary purpose was to provide informers in defense plants and Italian and German neighborhoods, it legitimated the Legion's political spying while containing it with FBI supervision. Some sixty thousand Legionnaires worked as informers, though the program provided little of use. Ex-FBI agents became important in the American Legion; one became head of the group's Americanization Commission within a week after he left the Bureau. In the later 1950s the head of the Crime Records Division was simultaneously public relations director for the Legion. Some ex-agents became private detectives specializing in anti-Communist sleuthing. Three former agents established a consulting firm with funding from two prominent anti-Communists, a businessman and Catholic priest, for collecting and publicizing information about people's political activities that the FBI itself could not legally reveal. They investigated employees for business clients and published Counterattack, a newsletter that listed supposed Communist ties of entertainers, union leaders, and others suspected of subversive activities. Their 1950 Red Channels became a major source for corporate blacklisting of entertainers. ${ }^{24}$ By the mid twentieth century political policing was an activity of both the state and officially authorized as well as tacitly approved private anti-Communist vigilante groups.

\section{PRIVATE DETECTIVES}

Private detectives are a conspicuous icon of American culture, made famous by dime novels and pulp magazines, books, television and movies. Private detection originated when police forces were modernized in the mid- $19^{\text {th }}$ century. Before the establishment of regular patrol forces, victims of robbery or burglary had to seek out a detective officer attached to criminal courts. The officer was essentially the victim's employee. Detectives developed networks of underground contacts, and usually located a thief through them. The officers offered to let the thief go free in exchange for a share in the value of the pawned loot. The victim received at least some of that share.

When police forces were established, this practice became illegal, "compounding a felony", and became a form of corruption practiced in secret. But some former police detectives decided to be open about it and established private agencies, the first in New York City in 1845. ${ }^{25}$ Many detectives were hired by people seeking divorce to discover acts of infidelity as the strict divorce laws of the mid-19 $19^{\text {th }}$ century required. Recovering stolen goods for people who had little confidence in the police, and serving bank and railroad victims of robbery became major areas for private investigators. Before developing separate detective divisions, even police departments hired private investigators. In New York City, with a well-developed but

\footnotetext{
23 Shrecker (1998, pp. 68-69).

24 Shrecker (1998, pp. 217-218).

25 Johnson (1979, pp. 45-51 \& 59-60).
} 
corrupt police force in the 1890 s, the District Attorney hired a Pinkerton detective to capture the notorious fence, "Ma'am" Mandelbaum. ${ }^{26}$

"Pinkerton" immediately comes to mind when thinking of nineteenth-century private detectives. Allen Pinkerton formed the first large-scale agency with a nationwide reach, with offices in New York, Chicago, Denver and other cities. He was expert at creating his own public image, ${ }^{27}$ becoming most famous as the unrelenting pursuer of western bank, stage coach, and train robbers. His agency was the first to develop a modern crime lab, and generally the private detectives were ahead of the police in adopting new criminal investigation techniques such as the Bertillon system of physical measurements.

\section{INDUSTRIAL POLICE}

Private policing entered the murky realm of political policing during the economic and social conflict of the later nineteenth century. Private forces became virtually unregulated delegates of state as well as capitalist power in a nation that had long rejected the concept of political policing by the government. Pinkerton had started out working for railroads to detect theft and embezzlement, moving on to investigate "trouble makers" among the workers. After the Civil War the railroad, coal, iron and steel magnates believed they had to protect their profits from workers' demands for better wages, conditions and hours. Private police working directly for industrialists were a more trustworthy alternative to local police or even state militias whose members came from the community of workers and sometimes balked at suppressing their neighbors. Usually though, local forces joined company police against workers. The Pinkerton firm was willing to provide strike breakers and labor spies for employers.

The Pinkerton Agency established its reputation in 1876-77 as a reliable ally of the employers when one of their detectives infiltrated the Mollie Maguires, a secret workers' organization in the Pennsylvania coal mines, and acted as an agent provocateur so that leaders could be arrested for crimes he persuaded them to commit. The other role of the Pinkertons was to provide guards to protect strike breakers from the hostility of workers. These guards were not detectives, or even permanent employees of the agency, but toughs hired as the need arose. The most notorious use of these guards was during the Pennsylvania Homestead steel strike in 1892. Reflecting the angry public response, Congress passed an 'Anti Pinkerton Act' in 1893, but that restricted only the Federal government from hiring Pinkerton or other strikebreakers. Pinkerton soon got out of that business, but other agencies like the Burns Detectives, 'King of Strikebreakers' Jim Farley, Corporations Auxiliary Company, Pearl Berghoff and Baldwin-Felts detectives also provided spies and strikebreakers, practices that continued through the 1930s. Henry Ford, the last automaker to sign union agreements in 1941, maintained his own 'service department' recruited from underworld characters as well as ex-cops and FBI

\footnotetext{
26 Holub (2007, pp. 143-147).

27 Weiss, (March 1986, pp. 87-107).
} 
agents. ${ }^{28}$ A Senate investigation revealed a well-developed system of political policing in many factories. ${ }^{29}$

Pennsylvania, the conflict-ridden American industrial heartland, provided the earliest example of integration of public and private policing as a state within the state. In 1865-1866 the legislature granted railroads, mining, and iron and steel companies the power to create private police forces, the Coal and Iron Police. Employers paid the state one dollar for a commission that allowed them to choose whomever they wished to exercise police powers of arrest and detention. The men wore a badge stamped "coal and iron police". The first contingent of these officers was under Pinkerton supervision, and in fact seems to have been identical with the Pinkerton 'guards'. Their functions were control of workers by weakening their unions and breaking strikes. Pennsylvania created a more sophisticated and better trained State Police in 1905, officially to protect the persons and property of people living in the countryside. Because of a law allowing them to arrest for trespassing (locked-out or picketing workers were legally trespassers) they proved quite useful in taking over strikebreaking from private forces. Nevertheless, the Coal and Iron Police continued until $1931 .^{30}$

Despite the late start for official political police in the U.S. during World War I, political policing had been going on for years, protecting the interests of industrial employers, which often seemed to be identical to those of the state itself. Not until the 1930s did the Federal government relinquish its support of the bosses against the workers.

Company police today serve as internal security forces to prevent embezzlement and theft of trade secrets in large corporations. In retail businesses they also deal with shoplifters or unruly customers, and patrol the public spaces of shopping malls and act for privately-funded 'business improvement districts' in cities. When dealing with company employees they form a parallel criminal justice system to the public one. The employers often do not want an embezzlement case to enter the public record, preferring to sanction the offender internally. Firing is the preferred punishment rather than charging the employee with a crime in court. Constitutional rights of people accused internally do not apply, and the matter is dealt with quietly and efficiently. The public system has a vested interest in this parallel structure, because full prosecution of all cases of embezzlement and industrial espionage would swamp the courts. ${ }^{31}$ While ordinary security guards are poorly trained and educated, their supervisors, often formerly from the public sector such as ex-police or FBI agents, occupy important well-paid places in the corporate hierarchy. People with police experience are in demand for corporate security, and in large firms they are given the opportunity to work with highly sophisticated detection technology that the public sector cannot afford. ${ }^{32}$

\footnotetext{
28 Weiss (1986, pp. 105-106).

29 United States Senate, Committee on Education and Labor, 'The 'little steel' strike and Citizens' Committees', Report no.151 (1941).

30 [http://www.micintyrepa.com/coalandironpolice.htm], retrieved 21 Nov. 2012.

31 Lipman, McGraw (July 1988, p. 57).

32 Lipman I. (July 1988, p. 89).
} 


\section{PRIVATE NATIONAL SECURITY}

Since the 9/11 a private internal and external state has grown beside the official apparatus of agencies to prevent future terrorism. Although the threat has been mainly external, when a few Americans receive terrorist training abroad and plot actions in the United States it becomes a domestic issue. The G.W. Bush administration defined counter-terrorism as a war, but in practice many aspects are a form of policing, i.e. prevention and detection. National security has become a mix of public agencies and private contractors who perform the government's work. There have always been military contractors who manufacture uniforms, weapons, and other war material. However, in the past there has been a limit, namely a prohibition against farming out of what was defined as inherently governmental work. The Bush Administration's belief in privatization of public services has led to corporations performing basic intelligence work in every governmental agency. A temporary emergency response to $9 / 11$ has become a permanent delegated state within the state: the government depends on them. About 1/3 of the people with top-secret security clearance are contractors, who enjoy corporate perks and salaries that are substantially more lucrative than those of civil servants. The Department of Homeland Security employs as many private as government workers. Sixty percent of the employees of its intelligence-gathering office work for contractors. Most of their work involves data collection and analysis, but these private companies "are the historians, the architects, the recruiters of the nation's most secretive agencies." Externally they provide security and many other aspects of the military. ${ }^{33}$ The pervasive role of private security corporations leads to questions of responsibility : are they more loyal to their shareholders than the government they serve? Is the government actually in control of its most secret operations $?^{34}$ One could, as some did, ask similar questions about the Pinkertons or the APL: to what extent should policing be delegated to private companies or groups with their own agendas?

\section{CONCLUSION}

American historians are reluctant to call the United States 'exceptional' compared to Western Europe. This is because the label usually suggests that America is 'better' than other nations. Nevertheless, the United States is unusual among Western nations for the significant role private policing has played in its history, often in co-operation with the state. This is not to say that private policing has not existed in Europe and Britain, but its role as a state within the state would not have been acceptable on the European continent where law enforcement and order maintenance were exclusively the functions of the State..$^{35}$

33 Priest, Arkin (2010) [http ://projects.washingtonpost.com/top-secret-america/ articles/national-security-inc/].

34 Washington Post, 21 July 2010.

35 For the spread of private policing in Europe today, see van Steden, Sarre (2007). For an interesting argument that private police is the new form used by the wealthy people in the 'information era' of the present, see Stansfield [https://www.ncjrs.gov/policing/rev125.htm], retrieved 24 Nov. 2012. For Britain see Williams (June 2008, pp. 190-205), Godfrey (1999a, 1999b). Williams discusses the hiring of public police by private individuals or organizations; Godfrey discusses the use of 
Public acceptance and state endorsement of private policing has long existed in the United States within the context of an ideology stressing the state's limits, while legitimating the state by its weakness. Pieter Spierenburg has argued that much of America's history of violence, partly due to the actions of organized and unorganized private policing, can be explained by the arrival of political democracy before development of a centralized state. ${ }^{36}$ Political democracy began roughly with states adopting universal white male suffrage beginning in the 1820 s, but a centralized national state developed in fits and starts after the Civil War and was not really consolidated until the early twentieth century. Unlike Europe, American citizens had a role in governing the state before they became used to a state monopoly of force. ${ }^{37}$

Private policing in various forms has not only existed alongside public policing, but often the state has tacitly or openly, evenly officially, supported vigilantes, citizen vice reformers, private detectives, and company police. Since the late twentieth century privatization has actually increased, from the amateur 'armed citizen' through a national security industry In a nation which takes as an article of faith that "that government is best that governs least", despite the growing complexity and reach of the national state, private policing has existed throughout its history, alongside or even as a recognized auxiliary to public policing - a delegated state within "The States".

Wilbur R. Miller

Dept. of History

State University of New York, Stony Brook wrmiller@notes.cc.sunysb.edu

\section{REFERENCES}

Brown, R.M. The American Vigilante Tradition, in Graham, H.D., Gurr, T.R. (Eds), Violence in America: Historical and Comparative Perspectives, New York, Signet Books, 1969, pp. 171-177.

Brown, R.M., No Duty to Retreat: Violence and Values in American History and Society, New York, Oxford University Press, 1991, [http://supreme.justia.com/cases/federal/ us/158/550/case.html].

[http://supreme.justia.com/cases/federal/us/256/335/case.html], both retrieved 23 Nov. 2012.

Friedman, L., Crime and Punishment in American History, New York, Basic Books, 1993.

Fronc, J., New York Undercover: Private Surveillance in the Progressive Era, Chicago, University of Chicago Press, 2009.

Godfrey, B., Law, Factory Discipline and 'Theft': The Impact of the Factory on Workplace Appropriation in mid - to late - 19th-Century Yorkshire, British Journal of Criminology, 1999a, 39, 1, pp. 56-71.

private agencies to monitor workplace theft. Today, the controversy over incompetent private policing of the London Olympics makes private police a live issue in Britain (see, e.g. [www.guardian. co.uk/business/2012/sep/28/g4s-boss-stays-olympics-shambles], retrieved 24 Nov. 2012) For the hiring of public police officers by Wall Street corporations in the U.S., see [http://www.counterpunch. org/2011/10/10/financial-giants-put-new-york-city-cops-on-their-payroll/], retrieved 24 Nov. 2012.

36 Spierenburg (2006, pp. 108-114).

37 Skowronek (1982). 
Godfrey, B., Judicial Impartiality and the Use of Criminal Law against Labour : The Sentencing of Workplace Appropriators in Northern England, 1840-1880, Crime, Histoire \& Sociétés/ Crime, History \& Societies, 1999b, 3, 2, pp. 57-72.

Hapgood, N. (ed.), Professional Patriots, New York, Albert \& Charles Boni, 1927.

Johnson, D.R., Policing the Urban Underworld, Philadelphia, Temple University Press, 1979.

Holub, R.L., 'Fredericka Marm' Mandelbaum, 'Queen of Fences': The Rise and Fall of a Female Immigrant Criminal Entrepreneur in Nineteenth-Century New York City, Columbia University $\mathrm{PhD}$ dissertation, 2007.

Lipman, I., Personnel Selection in the Private Security Industry, Annals of the American Academy of Political and Social Science, July 1988.

Lipman, M., McGraw, W.R., Employee Theft: A \$40 Billion Industry, Annals of the American Academy of Political and Social Science, July 1988.

McMillen, N.R., The Citizens' Council: Organized Resistance to the Second Reconstruction, 1954-1964, Urbana, University of Illinois Press, 1971.

Mennell, S. The American Civilizing Process, Cambridge, Polity Press, 2007.

Priest, D., Arkin, W., National Security Inc. (in series Top Secret America), Washington Post, 19-21 July 2010 [http://projects.washingtonpost.com/top-secret-america/articles/ national-security-inc/].

Shrecker, E., Many are the Crimes: McCarthyism in America, Boston, Little, Brown, 1998, pp. 61-63.

Skowronek, S., Building the New American State: the Expansion of National Administrative Capacities 1877-1920, New York, Cambridge University Press, 1982.

Spierenburg, P., Democracy Came too Early: a Tentative Explanation for the Problem of American Homicide, American Historical Review, 2006, 111.

Stansfield, R.T., Revisioning Community Policing [https://www.ncjrs.gov/policing/rev125. htm], retrieved 24 Nov. 2012.

Tocqueville, A. de, Democracy in America, Francis Bowen ed. (2 $2^{\text {nd }}$ ed.), Cambridge, MA, Sever and Francis, vol.I.

Taylor vs. Taintor, 1872: [http ://supreme.justia.com/cases/federal/us/83/366/case.html\#F15], retrieved 23 Nov. 2012.

van Steden, R., Sarre, R., The Growth of Private Security: Trends in the European Union, Security Journal, 2007, 20, pp. 222-235.

Weiss, R.P., Private Detective Agencies and Labour Discipline in the United States, 18551946, Historical Journal, 1986, 29, pp. 87-107.

Williams, C., Constables for Hire, Police and Society, 2008, 18, pp. 190-205. 